\title{
Krüppel-like factors: Three fingers in control
}

\author{
Shivalingappa K. Swamynathan
}

Department of Ophthalmology, University of Pittsburgh School of Medicine, Eye and Ear Institute, 203 Lothrop Street, Room 1025, Pittsburgh, PA 15213, USA

Tel: +1 412802 6437; Fax: +1 412647 5880; E-mail: Swamynathansk@upmc.edu

Date received (in revised form): 4th February 2010

\begin{abstract}
Krüppel-like factors (KLFs), members of the zinc-finger family of transcription factors capable of binding GC-rich sequences, have emerged as critical regulators of important functions all over the body. They are characterised by a highly conserved $\mathrm{C}$-terminal DNA-binding motif containing three $\mathrm{C} 2 \mathrm{H} 2$ zinc-finger domains, with variable $\mathrm{N}$-terminal regulatory domains. Currently, there are $17 \mathrm{KLFs}$ annotated in the human genome. In spite of their structural similarity to one another, the genes encoding different KLFs are scattered all over the genome. By virtue of their ability to activate and/or repress the expression of a large number of genes, KLFs regulate a diverse array of developmental events and cellular processes, such as erythropoiesis, cardiac remodelling, adipogenesis, maintenance of stem cells, epithelial barrier formation, control of cell proliferation and neoplasia, flow-mediated endothelial gene expression, skeletal and smooth muscle development, gluconeogenesis, monocyte activation, intestinal and conjunctival goblet cell development, retinal neuronal regeneration and neonatal lung development. Characteristic features, nomenclature, evolution and functional diversities of the human KLFs are reviewed here.
\end{abstract}

Keywords: gene expression, zinc-finger, transcription factor, Krüppel-like factor, DNA-binding

\section{Introduction}

Krüppel-like factors (KLFs) are members of the zinc-finger family of transcription factors named after their similarity to the Drosophila gap gene Krüppel. ${ }^{1}$ KLFs are characterised by a DNA-binding motif containing three well-conserved $\mathrm{C} 2 \mathrm{H} 2$ zinc-finger domains located in the carboxy terminal of the protein capable of binding GC-rich sequences, such as CACCC elements present in the proximal promoters of many eukaryotic genes. ${ }^{2-7}$ The transcriptional regulatory domains located in the amino terminal of different KLFs are variable, resulting in their ability to interact with co-activators and/or co-repressors, culminating in the activation or repression of a given promoter activity. The presence of variable structural motifs outside of the DNA-binding domain of the KLF family members is reflected in their functional diversity. $^{3,8}$ Characteristic features, nomenclature, evolution and functions of the human KLFs are reviewed here.

\section{Characteristic features of the zinc-finger domain in KLFs}

The 81-amino acid DNA-binding zinc-finger domain is highly conserved among the members of the KLF family, with more than 65 per cent amino acid sequence identity among the family members. The specific amino acids critical for DNA binding are highly conserved, imparting an ability to different KLFs that interact with similar cis-elements, 
such as GT boxes or GC-rich sequences like CACCC. The $\mathrm{C}_{2} \mathrm{H}_{2}$ zinc finger present in the KLFs consists of two short beta strands followed by an alpha helix. In the classical $\mathrm{C}_{2} \mathrm{H}_{2}$ zinc-finger domain, two conserved cysteines and histidines coordinate a zinc ion. The pattern of amino acid arrangement in a classical zinc finger is as follows: \#-X-C-X(1-5)-C-X3-\#-X5-\#-X2-H-X(3-6)-[H/C], where $\mathrm{C}, \mathrm{H}$ and $\mathrm{X}$ correspond to cysteine, histidine and any amino acid, respectively, and numbers indicate the number of residues separating the flanking amino acids. The amino acids that are important for the stable fold of the zinc finger are marked with the \# symbol. The amino acid occupying the final position can be either histidine or cysteine. The linker sequence in between the

Table I. Names, chromosomal locations, number of exons, sequence accession IDs, previous symbols and aliases, if any, for different KLFs.

\begin{tabular}{|c|c|c|c|c|c|}
\hline Gene symbol & Gene name & Gene location & $\begin{array}{l}\text { Number } \\
\text { of exons }\end{array}$ & Sequence IDs & $\begin{array}{l}\text { Previous symbols/ } \\
\text { aliases }\end{array}$ \\
\hline$K L F I$ & $\begin{array}{l}\text { Krüppel-like factor I } \\
\text { (erythroid) }\end{array}$ & $19 p|3.13-p| 3.12$ & 3 & U37I06 NM_006563 & EKLF \\
\hline KLF2 & $\begin{array}{l}\text { Krüppel-like factor } 2 \\
\text { (lung) }\end{array}$ & $19 p|3.13-p| 3.11$ & 3 & AFI 23344 & LKLF \\
\hline KLF3 & $\begin{array}{l}\text { Krüppel-like factor } 3 \\
\text { (basic) }\end{array}$ & $4 p \mid 4$ & 6 & AF285837 & BKLF \\
\hline KLF4 & $\begin{array}{l}\text { Krüppel-like factor } 4 \\
\text { (gut) }\end{array}$ & $9 q 31$ & 5 & AF022I84 NM_004235 & EZF, GKLF \\
\hline KLF5 & $\begin{array}{l}\text { Krüppel-like factor } 5 \\
\text { (intestinal) }\end{array}$ & $13 q 22.1$ & 4 & DI4520 & BTEB2, IKLF, CKLF \\
\hline KLF6 & Krüppel-like factor 6 & $10 p 15$ & 4 & U51869 & $\begin{array}{l}\text { BCDI, STI2, COPEB, } \\
\text { CPBP, GBF, Zf9, PACI }\end{array}$ \\
\hline KLF7 & $\begin{array}{l}\text { Krüppel-like factor } 7 \\
\text { (ubiquitous) }\end{array}$ & $2 q 32$ & 4 & AB0 I5I32 NM_003709 & UKLF \\
\hline KLF8 & Krüppel-like factor 8 & $X p I I .21$ & 6 & U28282 NM_007250 & $\begin{array}{l}\text { BKLF3, ZNF74I, } \\
\text { DXS74I }\end{array}$ \\
\hline KLF9 & Krüppel-like factor 9 & $9 q 13$ & 2 & BC06943I NM_00I206 & BTEBI \\
\hline KLFIO & Krüppel-like factor 10 & $8 q 22.2$ & 4 & U21847 & TIEG, EGRA, TIEGI \\
\hline KLFI I & Krüppel-like factor II & $2 p 25$ & 4 & AF028008 NM_003597 & TIEG2, TIEG3 \\
\hline$K L F / 2$ & Krüppel-like factor 12 & $13 q 22$ & 8 & AJ243274 NM_007249 & $\begin{array}{l}\text { AP-2rep, HSPCI22, } \\
\text { AP2REP }\end{array}$ \\
\hline KLFI3 & Krüppel-like factor 13 & $15 q 12$ & 2 & AFI 32599 NM_0I5995 & $\begin{array}{l}\text { RFLAT-I, BTEB3, } \\
\text { NSLPI, FKLF-2 }\end{array}$ \\
\hline$K L F / 4$ & Krüppel-like factor 14 & $7 q 32.3$ & I & AF490374 NM_I38693 & BTEB5 \\
\hline KLFI5 & Krüppel-like factor 15 & $3 q 13-q 21$ & 3 & AB029254 NM_0I4079 & KKLF \\
\hline KLFI6 & Krüppel-like factor 16 & $19 p \mid 3.3$ & 2 & AF327440 & NSLP2, BTEB4, DRRF \\
\hline KLFI 7 & Krüppel-like factor 17 & Ip34.I & 4 & BC049844 NM_I73484 & $\begin{array}{l}\text { ZNF393, Zfp393, } \\
\text { FLJ40160 }\end{array}$ \\
\hline
\end{tabular}


zinc-finger domains $(\mathrm{TGE}(\mathrm{R} / \mathrm{K}) \mathrm{P}(\mathrm{Y} / \mathrm{F}) \mathrm{X})$ is also highly conserved in KLF proteins. ${ }^{9}$

\section{Nomenclature of KLFs}

The nomenclature of KLFs has evolved over the years. KLFs were initially named after the tissue in which they were detected or highly expressed, such as erythroid KLF (EKLF or KLF1), ${ }^{10}$ lung KLF (LKLF or KLF2), ${ }^{11}$ gut-enriched KLF (GKLF/EZF or KLF4), ${ }^{12-15}$ and intestinal-enriched KLF (IKLF or KLF5; also called BTEB2). ${ }^{16,17}$ A few other KLFs were named after the elements they bound, such as the core promoter-binding protein (CPBP/ Zf9 or KLF6), ${ }^{18,19}$ basic transcription elementbinding protein (BTEB1 or KLF9), ${ }^{20}$ or by their physiological responses, such as transforming growth factor- $\beta$-inducible early genes 1 and 2 (TIEG1 and TIEG2 or KLF10 and KLF11, respectively). ${ }^{21,22}$ Considering that the tissue expression of KLFs, the range of their nucleotide recognition sequences and their ability to regulate diverse functions is much broader than initially understood, the use of numerical nomenclature based on the chronological order of discovery (such as KLF1, $\mathrm{KLF} 2, \mathrm{KLF} 3 . .$.$) is recommended by the Human$ Genome Organization Gene Nomenclature Committee (HGNC) to avoid misleading connotations providing partial descriptions of their expression and/or function. A search of the HGNC website (http://www.genenames.org/index.html) for 'Krüppel-like factor' on 26th January 2010 identified $17 \mathrm{KLF}$ genes in the human genome. Names, chromosomal locations, sequence accession IDs, previous symbols and aliases, if any, for these KLFs are given in Table 1. Several other related proteins, such as the members of the $\mathrm{Sp}$ family of proteins, GLI2, GLI3, and the pseudogene KLF7P, are not included in this list, for the sake of brevity.

\section{Evolution of KLFs}

KLFs are closely related to the Sp family of zinc-finger transcription factors, of which there are nine members in the human genome (Sp1-Sp9). Currently, there are 17 KLFs annotated in the human genome. The high level of conservation of structure and function of KLF proteins in different species is a reflection of their ancient evolutionary history. The 17 genes encoding different KLFs are scattered all over the human genome, and there are also $17 \mathrm{Klf}$ genes in the mouse genome. This indicates that these genes are ancient and suggests the involvement of gene duplications and translocations in their evolution.

The exon-intron organisation of human KLF genes is not well conserved. For example, while KLF12 has eight exons, KLF14 is encoded on a single exon (Table 1). Based on an extensive phylogenetic analysis with the amino acid sequences of KLF proteins from different species, it was proposed that the mammalian KLF genes have evolved in two phases - the first in the chordate

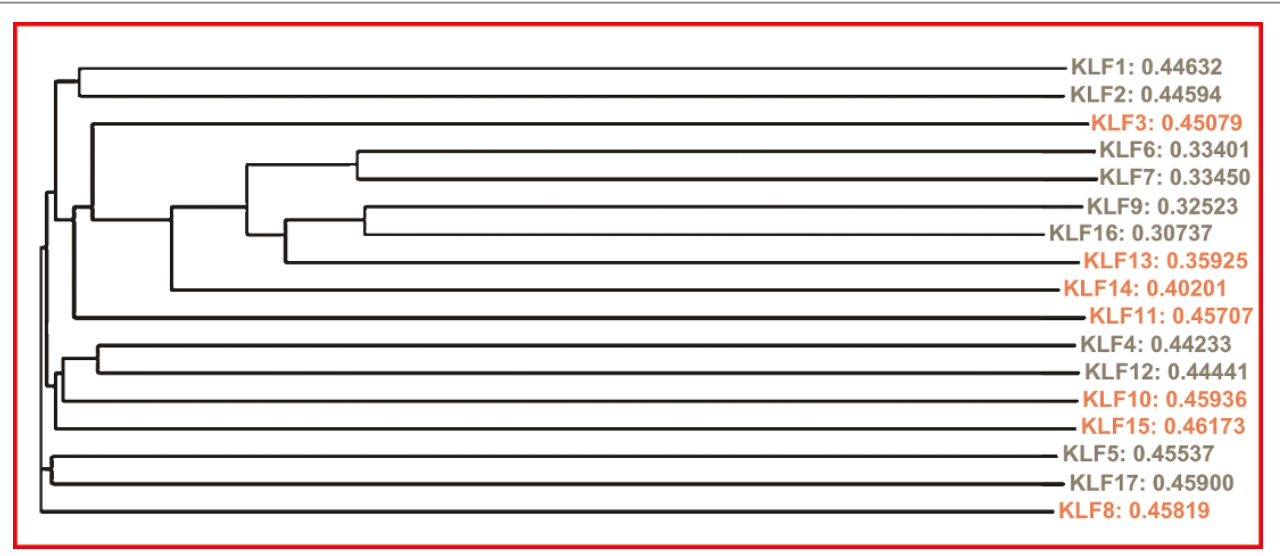

Figure I. Phylogenetic tree generated using the complete amino acid sequence of human KLF proteins by ClustalW2 web-based program (http://www.ebi.ac.uk/Tools/es/cgi-bin/clustalw2). Evolutionary distances are shown next to the corresponding names. 
Table 2. Expression pattern, interacting co-factors, effect on gene expression and known functions of different KLFs.

\begin{tabular}{|c|c|c|c|c|}
\hline Gene & Expression pattern & $\begin{array}{l}\text { Interacting } \\
\text { co-factors }\end{array}$ & Cellular function & References \\
\hline KLFI & Erythroid and mast cells & $\begin{array}{l}\text { P300/CBP, PCAF, } \\
\text { SWI.SNF and } m \sin 3 A\end{array}$ & Erythropoiesis, cell cycle & 25,26 \\
\hline KLF2 & $\begin{array}{l}\text { Lung, blood vessels, } \\
\text { lymphocytes }\end{array}$ & WWPI & $\begin{array}{l}\text { Adipogenesis, lung and blood } \\
\text { vessel development, T-cell } \\
\text { migration, monocyte activation }\end{array}$ & $27,28-30$ \\
\hline KLF3 & $\begin{array}{l}\text { Adipocytes, brain and erythroid } \\
\text { tissue }\end{array}$ & $\mathrm{CtBP} 2, \mathrm{FHL} 3$ & Adipogenesis & 31,32 \\
\hline KLF4 & $\begin{array}{l}\text { Gut, skin, cornea and several } \\
\text { other epithelial tissues }\end{array}$ & $\begin{array}{l}\text { HDAC, p } 300 / C B P \\
\text { b-catenin/TCF4, } \\
\text { Oct4, Sox } 2, \text { CtBP }\end{array}$ & $\begin{array}{l}\text { Epithelial barrier formation, } \\
\text { goblet cell development, } \\
\text { adipogenesis, stem cell } \\
\text { maintenance, control of cell } \\
\text { proliferation, regulation of } \\
\text { neuronal regeneration }\end{array}$ & $33-39$ \\
\hline KLF5 & $\begin{array}{l}\text { Gut, skin, lung, cornea and } \\
\text { several other epithelial tissues }\end{array}$ & $\begin{array}{l}\text { P53, HDACI, PARPI, } \\
\text { PIASI }\end{array}$ & $\begin{array}{l}\text { Cell growth, lung development, } \\
\text { cardiac remodelling, stem cell } \\
\text { maintenance }\end{array}$ & $40-45$ \\
\hline KLF6 & Ubiquitous & HDAC3 & Tumour suppressor & 46 \\
\hline KLF7 & Ubiquitous & MoKA & $\begin{array}{l}\text { Cell proliferation, neuronal } \\
\text { differentiation, olfactory bulb } \\
\text { development }\end{array}$ & $47-51$ \\
\hline KLF8 & Ubiquitous & $\mathrm{CtBP2}$ & $\begin{array}{l}\text { Cell proliferation, epithelial to } \\
\text { mesenchymal transition }\end{array}$ & $52-55$ \\
\hline KLF9 & Ubiquitous & $m \operatorname{Sin} 3 A$ & $\begin{array}{l}\text { Neurite outgrowth, carcinogen } \\
\text { metabolism, intestinal epithelial } \\
\text { development }\end{array}$ & $56-58$ \\
\hline KLFIO & Ubiquitous & $m \sin 3 A$ & Apoptosis, cell proliferation & 22,59 \\
\hline KLFI I & Ubiquitous & $m \sin 3 A, p 300$ & Cell proliferation & 60,61 \\
\hline$K L F / 2$ & Brain, kidney, liver and lung & $\mathrm{CtBPI}$ & Cancer progression & 62,63 \\
\hline$K L F / 3$ & Ubiquitous & $m \operatorname{Sin} 3 A, p 300, P C A F$ & $\begin{array}{l}\text { Cell proliferation, carcinogen } \\
\text { metabolism }\end{array}$ & 64,65 \\
\hline$K L F / 4$ & Ubiquitous & $\mathrm{mSin} 3 \mathrm{~A}, \mathrm{HDAC} 2$ & $\begin{array}{l}\text { Lipoprotein metabolism, basal } \\
\text { cell carcinoma, TGF- } \beta \text { signalling }\end{array}$ & $66-68$ \\
\hline KLFI5 & Ubiquitous & Spl, MEF2A & $\begin{array}{l}\text { Cardiomyocyte hypertrophy, } \\
\text { gluconeogenesis }\end{array}$ & $69-71$ \\
\hline KLFI6 & Ubiquitous & $m \operatorname{Sin} 3 A$ & $\begin{array}{l}\text { Carcinogen metabolism, cell } \\
\text { cycle }\end{array}$ & 65,72 \\
\hline KLFI 7 & Testis, brain and bone & Not known & $\begin{array}{l}\text { Epithelial-mesenchyme } \\
\text { transition }\end{array}$ & 73,74 \\
\hline
\end{tabular}


lineage, during the early emergence of vertebrates, and the second in the mammalian lineage. ${ }^{23}$ This phylogenetic analysis also identified six different ascidian zinc-finger proteins as the ancestral genes for the distinct subgroups of vertebrate $K L F$ genes. $^{23}$ In view of the intron-less nature of KLF14 and its homology with KLF16, it has been suggested that KLF14 is an ancient retrotransposed copy of KLF16. ${ }^{24}$ Phylogenetic analysis of the 17 human KLF complete amino acid sequences by the neighbour-joining method using the ClustalW2 program (http://www.ebi.ac. $\mathrm{uk} /$ Tools/es/cgi-bin/clustalw2) indicated that KLFs 5, 17 and 8 are related more to each other than to the rest of the KLFs, which are further grouped into two major clades (Figure 1). According to this analysis, KLFs 9 and 16 are the most recent KLFs to have diverged from each other, followed by KLFs 6 and 7 (Figure 1). This is consistent with the similar expression pattern, common ability to interact with $\mathrm{mSin} 3 \mathrm{~A}$ (a core component of a large multiprotein co-repressor complex with associated histone deacetylase enzymatic activity) and shared cellular function of cell cycle regulation attributed to KLFs 9 and 16 (Table 2).

\section{Functions of KLFs}

By virtue of their ability to activate and/or repress the expression of a large number of genes, KLFs regulate a diverse array of developmental events and cellular processes such as haematopoiesis, ${ }^{75,76}$ cardiac remodelling, ${ }^{77}$ adipogenesis, ${ }^{27,31,46,78-82}$ maintenance of stem cells, ${ }^{83-86}$ epithelial barrier formation, ${ }^{87-90}$ control of cell proliferation and neoplasia, ${ }^{91-93}$ flow-mediated endothelial gene expression, ${ }^{94,95}$ skeletal and smooth muscle development, ${ }^{96}$ gluconeogenesis, ${ }^{69}$ monocyte activation, intestinal and conjunctival goblet cell development, ${ }^{33,97}$ ocular surface integrity, ${ }^{33,34}$ retinal neuronal regeneration ${ }^{98}$ and neonatal lung development $^{40}$ (Table 2). This functional diversity of KLFs is consistent with the variable amino terminal regulatory domains in different KLFs that allow interaction with a diverse array of co-factors. For example,
KLFs 3,8 and 12 interact with carboxy-terminal binding protein $(\mathrm{CtBP})$ co-repressors through the PVDL(S/T) repressor domain, while KLFs 9, 10, 11, 13 and 16 interact with histone deacetylases (HDACs) through a Sin3 interaction domain (SID), both resulting in transcriptional repression. KLF4 interacts with co-activators such as p300 and $\mathrm{CBP}$ (cyclic-AMP-response-element-bindingprotein-binding-protein) to mediate transcriptional activation. KLF4 also has the ability to interact with HDACs, to repress transcription. The functional diversity of KLFs results in interesting conflicts, wherein different KLFs have antagonistic effect(s) on individual cellular processes. For example, KLF4 suppresses cell proliferation, while KLF5 promotes it. Similarly, adipogenesis is supported by KLFs 4, 5 and 15, but is suppressed by KLFs 2 and 3 .

\section{Future directions}

A large body of work over the past 25 years has established the KLFs as critical regulators of diverse functions in many parts of the body. In spite of this progress in our understanding of the properties of KLFs, much remains to be uncovered. In order fully to understand the properties of KLFs in diverse spatiotemporal contexts and physiological conditions, it is crucial to identify (a) the co-factors that they interact with; (b) their target genes; (c) the signal transduction pathways by which they are regulated; and (d) their unique tissue-specific roles using conditional knockouts. It is expected that these avenues of research will lead to exciting discoveries regarding the involvement of KLFs in human health and disease.

\section{Acknowledgments}

I apologise to those colleagues whose work could not be cited owing to space constraints. Work in the author's laboratory was supported by the NEI career development award 1K22EY016875-01, NEI core grant for vision research (5P30 EY08098-19), Research to Prevent Blindness and the Eye and Ear Foundation, Pittsburgh, PA, USA.

\section{References}

1. Wieschaus, E., Nusslein-Volhard, C. and Kluding, H. (1984), 'Kruppel, A gene whose activity is required early in the zygotic genome for normal embryonic segmentation', Dev. Biol. Vol. 104, pp. 172-186. 
2. Black, A.R., Black, J.D. and Azizkhan-Clifford, J. (2001), 'Sp1 and Kruppel-like factor family of transcription factors in cell growth regulation and cancer', J. Cell. Physiol. Vol. 188, pp. 143-160.

3. Dang, D.T., Pevsner, J. and Yang, V.W. (2000), 'The biology of the mammalian Kruppel-like family of transcription factors', Int. J. Biochem. Cell Biol. Vol. 32, pp. 1103-1121.

4. Kaczynski, J., Cook, T. and Urrutia, R. (2003), 'Sp1- and Kruppel-like transcription factors', Genome Biol. Vol. 4, p. 206.

5. Pearson, R., Fleetwood, J., Eaton, S., Crossley, M. et al. (2008), 'Kruppel-like transcription factors: A functional family', Int. J. Biochem. Cell Biol. Vol. 40, pp. 1996-2001.

6. Suske, G., Bruford, E. and Philipsen, S. (2005), 'Mammalian SP/ KLF transcription factors: Bring in the family', Genomics Vol. 85, pp. 551-556.

7. Turner, J. and Crossley, M. (1999), 'Mammalian Kruppel-like transcription factors: More than just a pretty finger', Trends Biochem. Sci. Vol. 24, pp. 236-240.

8. Geiman, D.E., Ton-That, H., Johnson, J.M. and Yang, V.W. (2000), 'Transactivation and growth suppression by the gut-enriched Kruppel-like factor (Kruppel-like factor 4) are dependent on acidic amino acid residues and protein-protein interaction', Nucleic Acids Res. Vol. 28, pp. 1106-1113.

9. Schuh, R., Aicher, W., Gaul, U., Cote, S. et al. (1986), 'A conserved family of nuclear proteins containing structural elements of the finger protein encoded by Kruppel, a Drosophila segmentation gene', Cell Vol. 47, pp.1025-1032.

10. Miller, I.J. and Bieker, J.J. (1993), 'A novel, erythroid cell-specific murine transcription factor that binds to the CACCC element and is related to the Kruppel family of nuclear proteins', Mol. Cell Biol. Vol.13, pp. $2776-2786$

11. Anderson, K.P., Kern, C.B., Crable, S.C. and Lingrel, J.B. (1995), 'Isolation of a gene encoding a functional zinc finger protein homologous to erythroid Kruppel-like factor: Identification of a new multigene family', Mol. Cell Biol. Vol. 15, pp. 5957-5965.

12. Shields, J.M. and Yang, V.W. (1998), 'Identification of the DNA sequence that interacts with the gut-enriched Kruppel-like factor', Nucleic Acids Res. Vol. 26, pp. 796-802.

13. Shields, J.M. and Yang, V.W. (1997), 'Two potent nuclear localization signals in the gut-enriched Kruppel-like factor define a subfamily of closely related Kruppel proteins', J. Biol. Chem. Vol. 272, pp. 18504-18507.

14. Shields, J.M., Christy, R.J. and Yang, V.W. (1996), 'Identification and characterization of a gene encoding a gut-enriched Kruppel-like factor expressed during growth arrest', J. Biol. Chem. Vol. 271, pp. 20009-20017.

15. Garrett-Sinha, L.A., Eberspaecher, H., Seldin, M.F. and de Crombrugghe, B. (1996), 'A gene for a novel zinc-finger protein expressed in differentiated epithelial cells and transiently in certain mesenchymal cells', J. Biol. Chem. Vol. 271, pp. 31384-31390.

16. Sogawa, K., Imataka, H., Yamasaki, Y., Kusume, H. et al. (1993), 'cDNA cloning and transcriptional properties of a novel GC box-binding protein, BTEB2', Nucleic Acids Res. Vol. 21, pp. 1527-1532.

17. Conkright, M.D., Wani, M.A., Anderson, K.P. and Lingrel, J.B. (1999), 'A gene encoding an intestinal-enriched member of the Kruppel-like factor family expressed in intestinal epithelial cells', Nucleic Acids Res. Vol. 27, pp. 1263-1270.

18. Koritschoner, N.P., Bocco, J.L., Panzetta-Dutari, G.M., Dumur, C.I. et al. (1997), 'A novel human zinc finger protein that interacts with the core promoter element of a TATA box-less gene', J. Biol. Chem. Vol. 272, pp. 9573-9580.

19. Ratziu, V., Lalazar, A., Wong, L., Dang, Q. et al. (1998), 'Zf9, a Kruppel-like transcription factor up-regulated in vivo during early hepatic fibrosis', Proc. Natl. Acad. Sci. USA Vol. 95, pp. 9500-9505.

20. Imataka, H., Sogawa, K., Yasumoto, K., Kikuchi, Y. et al. (1992), 'Two regulatory proteins that bind to the basic transcription element (BTE), a GC box sequence in the promoter region of the rat P-4501A1 gene', EMBO. J. Vol. 11, pp. 3663-3671.

21. Blok, L.J., Grossmann, M.E., Perry, J.E. and Tindall, D.J. (1995), "Characterization of an early growth response gene, which encodes a zinc finger transcription factor, potentially involved in cell cycle regulation', Mol. Endocrinol. Vol. 9, pp. 1610-1620.

22. Cook, T., Gebelein, B., Mesa, K., Mladek, A. et al. (1998), 'Molecular cloning and characterization of TIEG2 reveals a new subfamily of transforming growth factor-beta-inducible Sp1-like zinc finger-encoding genes involved in the regulation of cell growth', J. Biol. Chem. Vol. 273, pp. 25929-25936.

23. Chen, Z., Lei, T., Chen, X., Zhang, J. et al. (2009), 'Porcine KLF gene family: Structure, mapping, and phylogenetic analysis', Genomics Vol. 95 , pp. $111-119$

24. Parker-Katiraee, L., Carson, A.R., Yamada, T., Arnaud, P. et al. (2007), 'Identification of the imprinted KLF14 transcription factor undergoing human-specific accelerated evolution', PLoS Genet. Vol. 3, p. e65.

25. Hodge, D., Coghill, E., Keys, J., Maguire, T. et al. (2006), 'A global role for EKLF in definitive and primitive erythropoiesis', Blood Vol. 107, pp. $3359-3370$

26. Tallack, M.R., Keys, J.R., Humbert, P.O. and Perkins, A.C. (2009), 'EKLF/KLF1 controls cell cycle entry via direct regulation of E2f2', J. Biol. Chem. Vol. 284, pp. 20966-20974.

27. Banerjee, S.S., Feinberg, M.W., Watanabe, M., Gray, S. et al. (2003), 'The Kruppel-like factor KLF2 inhibits peroxisome proliferator-activated receptor-gamma expression and adipogenesis', J. Biol. Chem. Vol. 278, pp. $2581-2584$

28. Zhang, X., Srinivasan, S.V. and Lingrel, J.B. (2004), 'WWP1-dependent ubiquitination and degradation of the lung Kruppel-like factor, KLF2', Biochem. Biophys. Res. Commun. Vol. 316, pp. 139-148.

29. Sebzda, E., Zou, Z., Lee, J.S., Wang, T. et al. (2008), 'Transcription factor KLF2 regulates the migration of naive $\mathrm{T}$ cells by restricting chemokine receptor expression patterns', Nat. Immunol. Vol. 9, pp. 292-300.

30. Das, H., Kumar, A., Lin, Z., Patino, W.D. et al. (2006), 'Kruppel-like factor 2 (KLF2) regulates proinflammatory activation of monocytes', Proc. Natl. Acad. Sci. USA Vol. 103, pp. 6653-6658.

31. Sue, N., Jack, B.H., Eaton, S.A., Pearson, R.C. et al. (2008), 'Targeted disruption of the basic Kruppel-like factor gene (Klf3) reveals a role in adipogenesis', Mol. Cell Biol. Vol. 28, pp. 3967-3978.

32. Turner, J., Nicholas, H., Bishop, D., Matthews, J.M. et al. (2003), 'The LIM protein FHL3 binds basic Kruppel-like factor/Kruppel-like factor 3 and its co-repressor C-terminal-binding protein 2', J. Biol. Chem. Vol. 278, pp. 12786-12795.

33. Swamynathan, S.K., Katz, J.P., Kaestner, K.H., Ashery-Padan, R. et al. (2007), 'Conditional deletion of the mouse Klf4 gene results in corneal epithelial fragility, stromal edema, and loss of conjunctival goblet cells', Mol. Cell Biol. Vol. 27, pp. 182-194.

34. Swamynathan, S.K., Davis, J. and Piatigorsky, J. (2008), 'Identification of candidate Klf4 target genes reveals the molecular basis of the diverse regulatory roles of Klf4 in the mouse cornea', Invest. Ophthalmol. Vis. Sci. Vol. 49, pp. 3360-3370.

35. Evans, P.M., Chen, X., Zhang, W. and Liu, C. (2010), 'KLF4 interacts with beta-catenin/TCF4 and blocks p300/CBP recruitment by betacatenin', Mol. Cell. Biol. Vol. 30, pp. 372-381.

36. Evans, P.M., Zhang, W., Chen, X., Yang, J. et al. (2007), 'Kruppel-like factor 4 is acetylated by p300 and regulates gene transcription via modulation of histone acetylation', J. Biol. Chem. Vol. 282, pp. 33994-34002.

37. Wei, Z., Yan, Y., Zhang, P., Andrianakos, R. et al. (2009), 'Klf4 interacts directly with Oct4 and Sox 2 to promote reprogramming', Stem Cells Vol. 27, pp. 2969-2978.

38. Wei, D., Kanai, M., Jia, Z., Le, X. and Xie, K. (2008), 'Kruppel-like factor 4 induces p27Kip1 expression in and suppresses the growth and metastasis of human pancreatic cancer cells', Cancer Res. Vol. 68, pp. 4631-4639.

39. Young, R.D., Swamynathan, S.K., Boote, C., Mann, M. et al. (2009), 'Stromal edema in klf4 conditional null mouse cornea is associated with altered collagen fibril organization and reduced proteoglycans', Invest. Ophthalmol. Vis. Sci. Vol. 50, pp. 4155-4161.

40. Wan, H., Luo, F, Wert, S.E., Zhang, L. et al. (2008), 'Kruppel-like factor 5 is required for perinatal lung morphogenesis and function', Development Vol.135, pp. 2563-2572. 
41. Zhu, N., Gu, L., Findley, H.W., Chen, C. et al. (2006), 'KLF5 Interacts with p53 in regulating survivin expression in acute lymphoblastic leukemia', J. Biol. Chem. Vol. 281, pp. 14711-14718.

42. Matsumura, T., Suzuki, T., Aizawa, K., Munemosa, Y. et al. (2005), 'The deacetylase HDAC1 negatively regulates the cardiovascular transcription factor Kruppel-like factor 5 through direct interaction', J. Biol. Chem. Vol. 280, pp. 12123-12129

43. Suzuki, T., Nishi, T., Nagino, T., Sasaki, K. et al. (2007), 'Functional interaction between the transcription factor Kruppel-like factor 5 and poly(ADP-ribose) polymerase-1 in cardiovascular apoptosis', J. Biol. Chem. Vol. 282, pp. 9895-9901.

44. Du, J.X., Bialkowska, A.B, McConnell, B.B. and Yang, V.W. (2008), 'SUMOylation regulates nuclear localization of Kruppel-like factor 5', J. Biol. Chem. Vol. 283, pp. 31991-32002.

45. Du, J.X., Yun, C.C., Bialkowska, A. and Yang, V.W. (2007), 'Protein inhibitor of activated STAT1 interacts with and up-regulates activities of the pro-proliferative transcription factor Kruppel-like factor 5', J. Biol. Chem. Vol. 282, pp. 4782-4793.

46. Li, D., Yea, S., Li, S., Chen, Z. et al. (2005), 'Kruppel-like factor-6 promotes preadipocyte differentiation through histone deacetylase 3-dependent repression of DLK1', J. Biol. Chem. Vol. 280, pp. 26941-26952.

47. Smaldone, S., Laub, F., Else, C., Dragomir, C. et al. (2004), 'Identification of MoKA, a novel F-box protein that modulates Kruppel-like transcription factor 7 activity', Mol. Cell. Biol. Vol. 24, pp. 1058-1069.

48. Smaldone, S. and Ramirez, F. (2006), 'Multiple pathways regulate intracellular shuttling of MoKA, a co-activator of transcription factor KLF7', Nucleic Acids Res. Vol. 34, pp. 5060-5068.

49. Laub, F., Lei, L., Sumiyoshi, H., Kajimura, D. et al. (2005), 'Transcription factor KLF7 is important for neuronal morphogenesis in selected regions of the nervous system', Mol. Cell. Biol. Vol. 25, pp $5699-5711$

50. Lei, L., Laub, F., Lush, M., Romera, M. et al. (2005), 'The zinc finger transcription factor Klf7 is required for TrkA gene expression and development of nociceptive sensory neurons', Genes Dev. Vol. 19, pp. 1354-1364.

51. Lei, L., Zhou, J., Lin, L. and Parada, L.F. (2006), 'Brn3a and Klf7 cooperate to control TrkA expression in sensory neurons', Dev. Biol. Vol. 300, pp. 758-769.

52. van Vliet, J., Turner, J. and Crossley, M. (2000), 'Human Kruppel-like factor 8: A CACCC-box binding protein that associates with CtBP and represses transcription', Nucleic Acids Res. Vol. 28, pp. 1955-1962.

53. Wang, X. and Zhao, J. (2007), 'KLF8 transcription factor participates in oncogenic transformation', Oncogene Vol. 26, pp. 456-461.

54. Wang, X., Zheng, M., Liu, G., Xia, W. et al. (2007), 'Kruppel-like factor 8 induces epithelial to mesenchymal transition and epithelial cell invasion', Cancer Res. Vol. 67, pp. 7184-7193

55. Zhao, J., Bian, Z.C., Yee, K., Chen, B.P. et al. (2003), 'Identification of transcription factor KLF8 as a downstream target of focal adhesion kinase in its regulation of cyclin D1 and cell cycle progression', Mol. Cell Vol. 11, pp. 1503-1515

56. Simmen, F.A., Su, Y., Xiao, R., Zeng, Z. et al. (2008), 'The Kruppel-like factor 9 (KLF9) network in HEC-1-A endometrial carcinoma cells suggests the carcinogenic potential of dys-regulated KLF9 expression', Reprod. Biol. Endocrinol. Vol. 6, p. 41.

57. Simmen, F.A., Xiao, R., Velarde, M.C., Nicholson, R.D. et al. (2007), 'Dysregulation of intestinal crypt cell proliferation and villus cell migration in mice lacking Kruppel-like factor 9', Am. J. Physiol. Gastrointest. Liver Physiol. Vol. 292, pp. G1757-G1769.

58. Cayrou, C., Denver, R.J. and Puymirat, J. (2002), 'Suppression of the basic transcription element-binding protein in brain neuronal cultures inhibits thyroid hormone-induced neurite branching', Endocrinology Vol. 143, pp. 2242-2249.

59. Cook, T. and Urrutia, R. (2000), 'TIEG proteins join the Smads as TGF-beta-regulated transcription factors that control pancreatic cell growth', Am. J. Physiol. Gastrointest. Liver Physiol. Vol. 278, pp. G513-G521.
60. Fernandez-Zapico, M.E., Mladek, A., Ellenrieder, V., Folch-Puy, E. et al. (2003), 'An mSin3A interaction domain links the transcriptional activity of KLF11 with its role in growth regulation', EMBO J. Vol. 22, pp. 4748-4758.

61. Fernandez-Zapico, M.E., van Velkinburgh, J.C., Gutierrez-Aguilar, R., Neve, B. et al. (2009), 'MODY7 gene, KLF11, is a novel p300-dependent regulator of $\mathrm{Pdx}-1$ (MODY4) transcription in pancreatic islet beta cells', J. Biol. Chem. Vol. 284, pp. 36482-36490.

62. Schuierer, M., Hilger-Eversheim, K., Dobner, T., Bosserhoff, A.K. et al (2001), 'Induction of AP-2alpha expression by adenoviral infection involves inactivation of the AP-2rep transcriptional corepressor CtBP1', J. Biol. Chem. Vol. 276, pp. 27944-27949.

63. Nakamura, Y., Migita, T., Hosoda, F., Okada, N. et al. (2009), 'Kruppel-like factor 12 plays a significant role in poorly differentiated gastric cancer progression', Int. J. Cancer Vol. 125, pp. 1859-1867.

64. Kaczynski, J., Zhang, J.S., Ellenrieder, V., Conley, A. et al. (2001), 'The Sp1-like protein BTEB3 inhibits transcription via the basic transcription element box by interacting with $\mathrm{mSin} 3 \mathrm{~A}$ and HDAC-1 co-repressors and competing with Sp1', J. Biol. Chem. Vol. 276, pp. 36749-36756.

65. Kaczynski, J.A., Conley, A.A., Fernandez Zapico, M., Delgado, S.M. et al. (2002), 'Functional analysis of basic transcription element (BTE)-binding protein (BTEB) 3 and BTEB4, a novel Sp1-like protein, reveals a subfamily of transcriptional repressors for the BTE site of the cytochrome P4501A1 gene promoter', Biochem. J. Vol. 366, pp. 873-882.

66. Chasman, D.I., Pare, G., Mora, S., Hopewell, J.C. et al. (2009), 'Forty-three loci associated with plasma lipoprotein size, concentration, and cholesterol content in genome-wide analysis', PLoS Genet. Vol. 5, p. e1000730.

67. Stacey, S.N., Sulem, P., Masson, G., Gudjonsson, S.A. et al. (2009), 'New common variants affecting susceptibility to basal cell carcinoma', Nat. Genet. Vol. 41, pp. 909-914.

68. Truty, M.J., Lomberk, G., Fernandez-Zapico, M.E. and Urrutia, R. (2009), 'Silencing of the transforming growth factor-beta (TGFbeta) receptor II by Kruppel-like factor 14 underscores the importance of a negative feedback mechanism in TGFbeta signaling', J. Biol. Chem. Vol. 284, pp. 6291-6300.

69. Gray, S., Wang, B., Orihuela, Y., Hong, E.G. et al. (2007), 'Regulation of gluconeogenesis by Kruppel-like factor 15', Cell Metab. Vol. 5, pp. 305-312.

70. Yamamoto, J., Ikeda., Iguchi, H., Fujino, T. et al. (2004), 'A Kruppel-like factor KLF15 contributes fasting-induced transcriptional activation of mitochondrial acetyl-CoA synthetase gene AceCS2', J. Biol. Chem. Vol. 279, pp. 16954-16962.

71. Fisch, S., Gray, S., Heymans, S., Halder, S.M. et al. (2007), 'Kruppel-like factor 15 is a regulator of cardiomyocyte hypertrophy', Proc. Natl. Acad. Sci. USA Vol. 104, pp. 7074-7079.

72. Sakaguchi, M., Sonegawa, H., Nukui, T., Sakaguchi, Y. et al. (2005), 'Bifurcated converging pathways for high $\mathrm{Ca} 2+-$ and TGFbeta-induced inhibition of growth of normal human keratinocytes', Proc. Natl. Acad. Sci. USA Vol. 102, pp. 13921-13926.

73. van Vliet, J., Crofts, L.A., Quinlan, K.G., Czolij, R. et al. (2006), 'Human KLF17 is a new member of the Sp/KLF family of transcription factors', Genomics Vol. 87, pp. 474-482.

74. Gumireddy, K., Li, A., Gimotty, P.A., Klein-Szanto, A.J. et al. (2009), 'KLF17 is a negative regulator of epithelial-mesenchymal transition and metastasis in breast cancer', Nat. Cell. Biol. Vol. 11, pp. 1297-1304.

75. Nuez, B., Michalovich, D., Bygrave, A., Ploemacher, R. et al. (1995), 'Defective haematopoiesis in fetal liver resulting from inactivation of the EKLF gene', Nature Vol. 375, pp. 316-318.

76. Drissen, R., von Lindern, M., Kolbus, A., Driegen, S. et al. (2005), 'The erythroid phenotype of EKLF-null mice: Defects in hemoglobin metabolism and membrane stability', Mol. Cell Biol. Vol. 25, pp. 5205-5214.

77. Shindo, T., Manabe, I., Fukushima, Y., Tobe, K. et al. (2002), 'Kruppel-like zinc-finger transcription factor KLF5/BTEB2 is a target for angiotensin II signaling and an essential regulator of cardiovascular remodeling', Nat. Med. Vol. 8, pp. 856-863. 
78. Brey, C.W., Nelder, M.P., Hailemariam, T., Gaugler, R. et al. (2009), 'Kruppel-like family of transcription factors: An emerging new frontier in fat biology', Int. J. Biol. Sci. Vol. 5, pp. 622-636.

79. Eaton, S.A., Funnell, A.P., Sue, N., Nicholas, H. et al. (2008), 'A network of Kruppel-like Factors (Klfs) (2008), 'Klf8 is repressed by Klf3 and activated by Klf1 in vivo', J. Biol. Chem. Vol. 283, pp. 26937-26947.

80. Birsoy, K., Chen, Z. and Friedman, J. (2008), 'Transcriptional regulation of adipogenesis by KLF4', Cell Metab. Vol. 7, pp. 339-347.

81. Oishi, Y., Manabe, I., Tobe, K., Tsushima, K. et al. (2005), 'Kruppel-like transcription factor KLF5 is a key regulator of adipocyte differentiation', Cell Metab. Vol. 1, pp. 27-39.

82. Mori, T., Sakaue, H., Iguchi, H., Gomi, H. et al. (2005), 'Role of Kruppel-like factor 15 (KLF15) in transcriptional regulation of adipogenesis', J. Biol. Chem. Vol. 280, pp. 12867-12875.

83. Ema, M., Mori, D., Niwa, H., Hasegawa, Y. et al. (2008), 'Kruppel-like factor 5 is essential for blastocyst development and the normal selfrenewal of mouse ESCs', Cell Stem Cell Vol. 3, pp. 555-567.

84. Jiang, J., Chan, Y.S., Loh, Y.H., Cai, J. et al. (2008), 'A core Klf circuitry regulates self-renewal of embryonic stem cells', Nat. Cell Biol. Vol. 10, pp. $353-360$

85. Park, I.H., Zhao, R., West, J.A., Yabuuchi, A. et al. (2008), 'Reprogramming of human somatic cells to pluripotency with defined factors', Nature Vol. 451, pp. 141-146.

86. Parisi, S., Passaro, F, Aloia, L., Manabe, I. et al. (2008), 'Klf5 is involved in self-renewal of mouse embryonic stem cells', J. Cell Sci. Vol. 121, pp. 2629-2634

87. Patel, S., Xi, Z.F, Seo, E.Y., McGaughey, D. et al. (2006), 'Klf4 and corticosteroids activate an overlapping set of transcriptional targets to accelerate in utero epidermal barrier acquisition', Proc. Natl. Acad. Sci. USA Vol. 103, pp. 18668-18673.
88. Jaubert, J., Cheng, J. and Segre, J.A. (2003), 'Ectopic expression of kruppel like factor 4 (Klf4) accelerates formation of the epidermal permeability barrier', Development Vol. 130, pp. 2767-2777.

89. Segre, J.A., Bauer, C. and Fuchs, E. (1999), 'Klf4 is a transcription factor required for establishing the barrier function of the skin', Nat. Genet. Vol. 22, pp. 356-360.

90. McConnell, B.B., Ghaleb, A.M., Nandan, M.O. and Yang, V.W. (2007), 'The diverse functions of Kruppel-like factors 4 and 5 in epithelial biology and pathobiology', Bioessays Vol. 29, pp. 549-557.

91. Dong, J.T. and Chen, C. (2009), 'Essential role of KLF5 transcription factor in cell proliferation and differentiation and its implications for human diseases', Cell Mol. Life Sci. Vol. 66, pp. 2691-2706.

92. Evans, P.M. and Liu, C. (2008), 'Roles of Kruppel-like factor 4 in normal homeostasis, cancer and stem cells', Acta Biochim. Biophys. Sin. (Shanghai) Vol. 40, pp. 554-564.

93. Rowland, B.D. and Peeper, D.S. (2006), 'KLF4, p21 and context-dependent opposing forces in cancer', Nat. Rev. Cancer Vol. 6, pp. 11-23.

94. De Val, S. and Black, B.L. (2009), 'Transcriptional control of endothelial cell development', Dev. Cell Vol. 16, pp. 180-195.

95. Boon, R.A. and Horrevoets, A.J. (2009), 'Key transcriptional regulators of the vasoprotective effects of shear stress', Hamostaseologie Vol. 29, pp. $39-43$.

96. Haldar, S.M., Ibrahim, O.A. and Jain, M.K. (2007), 'Kruppel-like factors (KLFs) in muscle biology', J. Mol. Cell Cardiol. Vol. 43, pp. 1-10.

97. Katz, J.P., Perreault, N., Goldstein, B.G., Lee, C.S. et al. (2002), 'The zinc-finger transcription factor Klf4 is required for terminal differentiation of goblet cells in the colon', Development Vol. 129, pp. 2619-2628.

98. Moore, D.L., Blackmore, M.G., Hu, Y., Kaestner, K.H. et al. (2009), 'KLF family members regulate intrinsic axon regeneration ability', Science Vol. 326, pp. 298-301. 